\title{
Role of Social Media Marketing Activities (SMMAs) in Apparel Brands Customer Response: A Moderated Mediation Analysis
}

\author{
Zobi Khan ${ }^{1}$, Yongzhong Yang ${ }^{1, *}$, Mohsin Shafi ${ }^{2}$ and Ruo Yang ${ }^{1}$ \\ 1 Business School, Sichuan University, Chengdu 610065, China; zobi_khan@stu.scu.edu.cn (Z.K.); \\ yrstone@163.com (R.Y.) \\ 2 Center for Trans-Himalaya Studies, Leshan Normal University, Leshan 614000, China; \\ mohsin_shafimemon@yahoo.com \\ * Correspondence: yangyongzhong@scu.edu.cn
}

Received: 13 August 2019; Accepted: 17 September 2019; Published: 20 September 2019

\begin{abstract}
This study analyzes the influence of apparel/clothing brand social media marketing activities (SMMAs) on brand equity and customer response in Pakistan. First, the current SMMAs are examined; then, we propose new attributes, i.e., fundamental social media marketing activities (FSMMAs) and sophisticated social media marketing activities (SSMMAs) such as interactions, sharing, and trendiness. Second, the influence of innovative components, i.e., FSMMAs and SSMMAs, are analyzed regarding brand equity and customer response toward apparel brands. A survey was conducted with a total of 406 Pakistani customers who used apparel brands, and the collected data were analyzed through confirmatory factor analysis (CFA) and Hayes PROCESS macro in SPSS. From the empirical results, we concluded that apparel brand equity (i.e., brand awareness, brand image) significantly mediates the relationship between FSMMAs and customer response (price premium willingness, customer loyalty). Moreover, it is also determined that SSMMAs moderate the indirect association of FSMMAs and customer response via brand equity.
\end{abstract}

Keywords: sustainable apparel brands; social media marketing activities; brand equity; customer response; price premium; customer loyalty

\section{Introduction}

Nowadays, the definition of social media is not only limited to people connecting, communicating, and interacting with each other through instant messaging, but also provides a platform for consumers to learn about brands, share brands' content, and interact with brands [1,2]. The introduction of social media has opened many new routes for companies and brands to attract and engage their customers effectively [3-5]. The evolving marketing feature of social media can be a powerful tool for brand popularity and business sustainability [1,6-9]. The applications of social media are increasing day by day; around two-thirds of all Internet users are active social media users [10,11]. Pakistan is the 10th largest Internet user in the world, with 62 million users [12]; there has been a rapid growth in the usage of social media, where Facebook was noted to be one of the most widely used social media platforms, with a record of 19 million users [13]. According to the Stats S. G report [14], the statistics of social media market share in Pakistan by platform from January 2018 to January 2019 was $83.08 \%$ Facebook, $5.42 \%$ Twitter, and $4.09 \%$ YouTube.

Social media extensively captured the attention of researchers and marketers for brand management and promotion activities-yet despite the popularity and scholarly interest, it still has persistent challenges $[4,10,15-17]$. The primary concern is the difficulty in measuring the 
influence of social media marketing activities (SMMAs) on key brand success measures [18,19]. The previous research of SMMAs in the context of different brands marketing was mostly exploratory, where the empirical study did little to address all the challenges of the current marketing trends $[11,20]$. This study aims to focus on how SMMAs affect customer response (customer loyalty and price premium willingness) in Pakistani apparel brand market.

The previous research investigated the impact of SMMAs (i.e., interaction, word of mouth (WoM), trendiness, entertainment, and customization) on brand equity, value equity, relationship equity, customer equity, customer preference, loyalty, price premium, and purchase intention in different industries (e.g., luxury brands and the airline industry) [21-23]. The authors found a significant effect on the aforementioned associations, which increased the interest of SMMAs for both researchers and practitioners $[8,17,18]$. The concept of brand equity and its effectiveness is partially studied in the context of social media marketing (SMM) in the literature [21-23]. The previous research supports the promotional activities of social media channels for luxury brands and the airline industry [21-24]. The authors in [21,23] determined that brand equity, i.e., brand image and brand awareness, plays a mediating role between SMMAs and customer response. The state of SMMs in Pakistan has developed exponentially [25]. Most of the industries adopted social media as a marketing tool to attract their customers [13,25-27]. A company should not directly jump to the social media channel for promotions; instead, they should develop strategic Facebook, Twitter, and YouTube marketing activities beforehand [24]. The online presence of fashion brands (e.g., apparel/clothing) on social media provides a platform for customers to associate with brands [28]. There is fierce competition among different apparel brands in Pakistan to capture the market [29]. Therefore, the primary concern to be addressed is the expending of business sustainability in apparel brand SMM.

This study contributes to the previous research by proposing a comprehensive framework that shows how SMMAs affect brand equity and consumer behavior toward apparel/clothing brands in Pakistan. Differing from the previous studies [21-23], here, the existing SMMAs (interaction, WoM, trendiness, entertainment, and customization) are extended and subdivided into two parts, i.e., fundamental social media marketing activities (FSMMAs) and sophisticated social media marketing activities (SSMMAs). This paper has FOUR broad objectives. First, this study aims to assess the direct influence of FSMMAs (likes/followers/subscribers) on apparel brands' equity (i.e., brand image and brand awareness). The second objective is to investigate the effect of FSMMAs on customer response (i.e., customer loyalty and price premium willingness) toward Pakistani apparel brands. The third objective is to analyze the mediation effect of brand equity (i.e., brand image and brand awareness) on the relationship between FSMMAs and customer response. The fourth objective is to measure the moderating effect of SSMMAs (i.e., interaction, sharing, and trendiness) over the mediation effect of FSMMAs, brand equity, and customer response (moderated mediation). This research explores these relationships by analyzing pioneering apparel brands in Pakistan. The selected social media for SMMAs assessment in Pakistan were Facebook, YouTube, and Twitter. In the end, the study presents the following questions.

1. Do FSMMAs on social media affect apparel brands' equity?

2. Do FSMMAs on social media affect apparel brands' customers' response?

3. Does the apparel brand's equity mediate the relationship between FSMMAs and customer response?

4. Do SSMMAs moderate the relationship between FSMMAs and brand equity?

To answer these questions, this study conducted a quantitative survey of Pakistani apparel brands' customers and tested it through the conditional PROCESS macro in SPSS [30]. The rest of the paper is organized as follows. Section 2 describes the theoretical foundation and previous work. Section 3 deliberates the proposed research design. Section 4 explains the empirical results. Section 5 presents the discussion and practical implications. Finally, Section 6 concludes the paper based on the empirical results. 


\section{Literature Review}

\subsection{Theoretical Foundation}

The theoretical background of this research is based on the Gurevitch, Katz, and Blumler theory called Uses and Gratification Theory (UGT) [31]. Although this theory demonstrates consumer behavior on conventional media, with the development of the Internet and new platforms of interactions, UGT theory has also been applied to social media research $[13,32]$. The application of UGT in the context of this study is based on the simple assumption that the consumers will be self-conscious and active contributors on social media platforms [13]. However, it is also acceptable that the consumers' response is also dependent on their own goals rather than social media advertising. Thus, this theory assumes that social media use is objective-oriented, i.e., the consumers will search for different brands on social media before purchasing for their gratification [33].

Numerous social media studies already considered the application of the UGT for exploring its outcomes in different contexts [34-37], such as for identifying the factors that could increase consumers' engagement toward a specific brand through social media platform marketing [38]. Similarly, the UGT is also applied in developing hypotheses that could assess the motivation of positive engagement behavior on brand usage intensity, brand strength, and brand loyalty [39]. The literature includes many studies where the UGT has been used in support of traditional as well as technological media platforms as a source of understanding how the emotive, intellectual, and other emergent desires of the consumers are gratified. This theory has also been considered in specific cases as a resource for understanding how different social media had successfully attracted consumer responses [13]. The literature also has employed the UGT extensively to explain why users use particular social media [36-38,40]. The use of social media varies from person to person, e.g., people use it for status seeking, information collecting, socializing, and entertainment. In the context of marketing, Smith [41] found that $88 \%$ of marketers are using social media as a marketing tool, where a total of USD 60 billion is investing annually for social media promotions in the U.S. Based on the popularity and successful applications of the UGT, we also concluded that this theory fits well with our current study, which aims to investigate how SMMAs influence consumers' response toward apparel brands in Pakistan.

\subsection{Social Media Marketing Activities (SMMAs)}

Nowadays, social media are widely considered as a promising platform to conduct promotional activities by modern businesses to effectively engage and attract their customers [42,43]. According to the review paper, around $89 \%$ of articles support the role of social media in improving customers' perception and awareness [44]. Social media have been adopted over a wide range of different contexts (i.e., social life, financial life, business life, educational sector, and political life) in Pakistan [45]. The apparel/clothing brands in Pakistan are evolving rapidly by introducing new fashions and designs, which creates a big challenge for marketers to shape the brands and attract customers [46,47]. Most of the previous work pointed out how the textile industry in Pakistan is attracting their customers through the effective use of social media marketing $[13,47]$. The present study in the Pakistani textile industry broadly considered the impact of social media (Facebook) on consumer behaviors where the influence of relevant marketing components (likes, interaction, sharing, and trendiness, etc.) was ignored [47].

Kim and Ko [22] and Godey et al. [21] divided luxury brands' SMMAs characteristics into five potential dimensions, i.e., interaction, entertainment, trendiness, word-of-mouth (WoM), and customization. Later, Seo and Park [23] adopted the same aspects in the airline industry. This study further narrows down the existing SMMAs of luxury brands and the airline industry [21-23], and examines its impact on Pakistani apparel brands' customers.

The authors [48] analyzed the impact of Facebook likes and sharing on customer purchase intention. Smith and Gallicano, [49] compared YouTube, Twitter, and Facebook, and found that Facebook and Twitter are more robust social media platforms that not only interact with the customer, but also create and present the brands' stories. The authors [50] analyzed the impact of Facebook 
likes, Twitter followers, Facebook links posted (sharing), and Twitter links posted (sharing) on student recruitment performance in the education sector. This study uses a survey to measure the influence of Facebook likes, Twitter followers, and YouTube viewers/subscribers on apparel brand equity and customers response. Furthermore, it also analyzes the moderating effect of the sharing component over likes/followers/viewers/subscribers and brand equity.

Social media interaction is a useful channel for consumers to discuss and exchange ideas [3,51]. Interactions facilitate users to contribute to social media platforms concerning a particular brand [52]. Social media interactions play a significant role in changing the dynamics of brand-customer communications. This study defines interaction and opinion sharing regarding a specific apparel brand as a discussion, and assesses its impact on brand equity and customer response. The interaction in this research acts as a moderator between FSMMAs and brand equity.

Trendiness refers to the newest and trendiest information about a product or service [11,22]. Most consumers select clothing based on the appearance of others wearing the same clothes [21]. Additionally, social media avails the most up-to-date trendy and news information. Thus, social media is a platform through which to discover the most updated products [53]. According to Sano [54], social media decreases these uncertainties by sanctioning consumers to interact with companies and check for trendy and new information.

\subsection{SMMAs Impacts on Brand Equity (Brand Awareness, Brand Image)}

Brand equity describes the assets and debts associated with a particular brand name and/or symbol [21]. Brand awareness depends on the conceptualization of brand equity [23]. Brand awareness determines that the consumers know the brand name, logo, symbol, etc. [22]. The awareness of a brand increases the possibility of that brand selection due to customer interest [55]. Kim and Ko [22] assessed the influenced of luxury brands' SMMAs (entertainment, interaction, trendiness, customization, and word of mouth) on well-known brand equity dimensions (i.e., brand awareness and brand image), and evaluated their impacts on customer response. Similarly, Seo and Park [23] also analyzed the influence of Kim and Ko [22] through investigating the impact of SMMAs in the airline industry on brand equity and customer response. Their results indicated that trendiness was the most significant component, which had a considerable impact on brand awareness and brand image.

Molinillo, Ekinci, and Japutra [56] used brand equity as a predictor of brand satisfaction, brand trust, and brand loyalty. The authors [21] measured brands' marketing activities on social media as a general concept that includes five features (entertainment, interaction, trendiness, customization, and word of mouth). They also found that marketing components had a significant positive impact on brand equity (i.e., brand awareness and brand image). In the light of the previous study, this research focuses on the direct impact of FSMMAs (likes/followers/viewers/subscribers) over brand equity and also subsequently measures the moderating effect of SSMMAs (interaction, sharing, trendiness) over FSMMAs and brand equity.

\subsection{Influence of FSMMAs and Brand Equity on Customer Response}

\subsubsection{Price Premium Willingness}

The price premium willingness is most likely a potential direct antecedent of customer purchasing behavior [21]. According to Netemeyer et al. [57], the willingness to pay a price premium is the amount that customers are willing to pay for a specific brand as compared to others. The study of Kim and Ko [22] constitutes the impact of SMMAs over price premium willingness. Leung, Bai, and Stahura [58] empirically found that customers' behavioral intention to buy is dependent on the customers' attitude related to an organization's Twitter and Facebook advertisements. 


\subsubsection{Customer Loyalty}

Customer loyalty refers to the probability that your customers will repeat business with you [21]. Gamboa and Gonçalves [59] demonstrated the part of Facebook on improving customers' loyalty. They stated that fans of the Zara brand on Facebook were found to have significant trust, were more pleased, and indicated a high price premium willingness, and accordingly, they expressed more loyalty toward Zara than those who did not follow Zara on Facebook. Christou [60] showed that the components of social media brands have a substantial part in explaining the customers' trust, which further reflects positively on brand loyalty. From the existing research, this study proposes that apparel brands' marketing activities on social media have a direct influence on customer responses, such as their loyalty and price premium willingness.

\section{Research Design}

\subsection{Conceptual Model}

This study investigates the influence of SMMAs on customer response toward a specific apparel brand in Pakistan. All the potential variables are associated with mediation and moderated mediation effects. The complete research model based on the literature is shown in Figure 1.

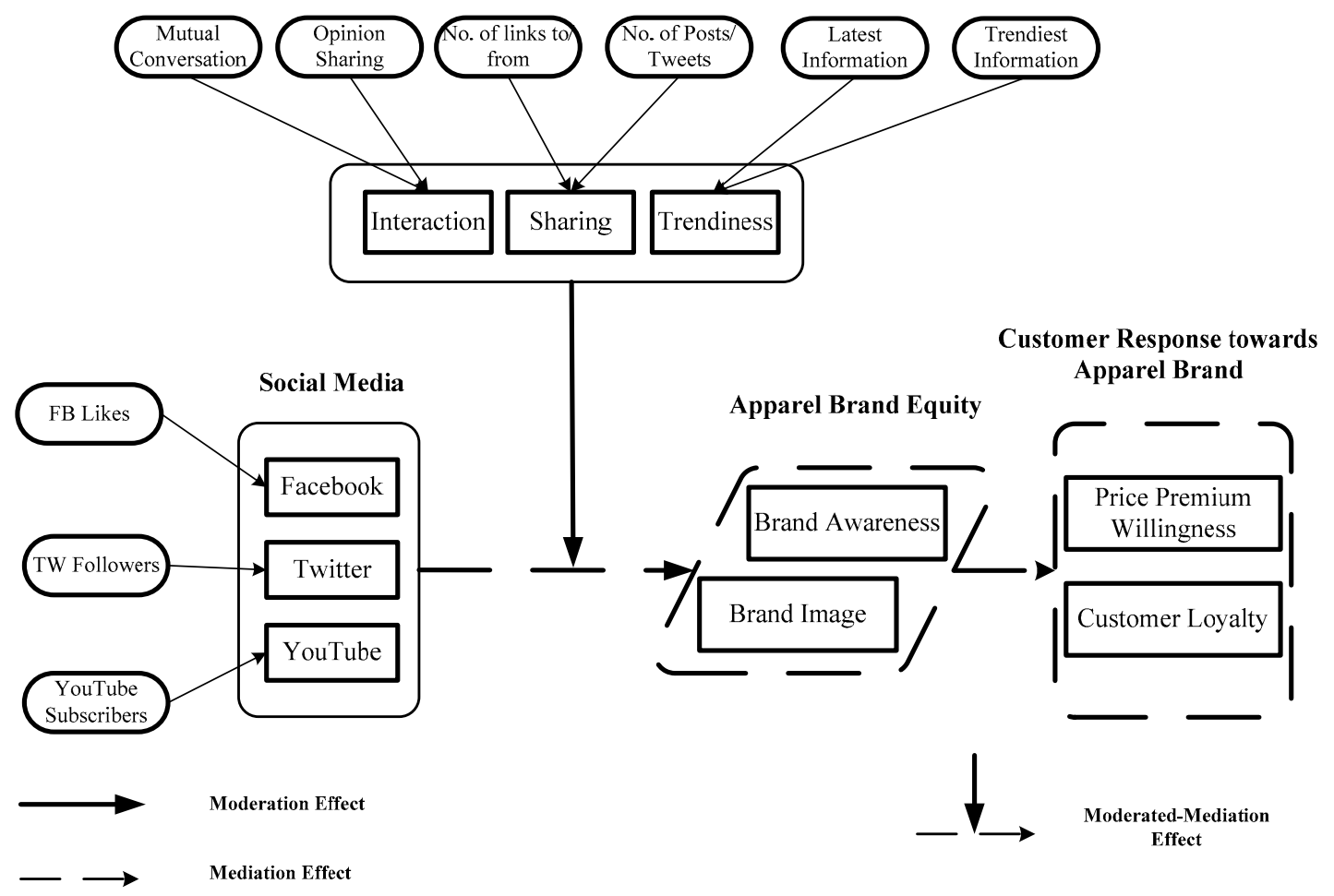

Figure 1. Conceptual research framework.

\subsection{Hypotheses Development}

\subsubsection{Direct and Indirect Association of FSMMAs on Customer Response via Apparel Brand Equity}

The authors [61] investigated the effects of social media activities on brand image and customer purchase intention. Similarly, Godey et al. [21] also concluded that social media activities have a positive influence on brand equity and customer behaviors. Seo and Park [23] investigated the relative importance of SMMAs, and found that each marketing activity significantly affects customer loyalty and price premium willingness. Crofton and Parker [62] indicated that social media marketing mechanism has a considerable and positive influence on the firms' ability to enhance their loyalty and 
purchasing behavior. In this study, the following hypotheses on FSMMAs, price premium willingness, and customer loyalty are drawn from the literature.

Hypothesis 1 (H1). Fundamental social media marketing activities (FSMMAs) have a positive and direct influence on consumers' price premium willingness for apparel brands.

Hypothesis 2 (H2). Fundamental social media marketing activities (FSMMAs) have a positive and direct influence on apparel brands' customer loyalty.

Seo and Park [23] used brand equity as a mediator between SMMAs and customer response. Similarly, Kim and Ko [22] also empirically examined the influence of SMMAs on the customer loyalty (also discussed in the literature). Their empirical results showed that SMMAs affect both the customers' intention to purchase and the customer response via a mediating impact of value equity and brand equity. According to Jiang, Li, Liu, and Chang [63], the difference in the customer response is dependent on brand marketing, preferences, behaviors, and reaction differences, depending on the brand awareness and brand image. In light of the literature mentioned above, we drew the following hypotheses.

Hypothesis 3 (H3). Apparel brand awareness mediates the relationship between FSMMAs and apparel brands' price premium willingness.

Hypothesis 4 (H4). Apparel brand awareness mediates the relationship between FSMMAs and apparel brand customer loyalty.

Hypothesis 5 (H5). Apparel brand image mediates the relationship between FSMMAs and apparel brand price premium willingness.

Hypothesis 6 (H6). Apparel brand image mediates the relationship between FSMMAs and apparel brand customer loyalty.

\subsubsection{Moderated Mediation Effect}

Social media interaction is an essential method of communication between brands and customers [51]. Brand-related industries are sharing unique information to increase their credibility and attraction in the market [52]. The authors [50] considered user interaction and links posted (sharing) as moderators between Facebook likes/Twitter followers and Universities and Colleges Admissions Service (UCAS) demand, and found that both moderators significantly moderate the association. According to Muntinga et al. [52] and Godey et al., [21], trendy information (latest news and hot discussion) on social media covers four sub-motivations: surveillance, knowledge, pre-purchase information, and inspiration.

The strength of the association between social media advertisement and brand equity can be moderated with the help of inter-interaction among customers, and between customers and the company [64]. Similarly, the utilization of brand-related posts and trendy information drives the attention of customers toward the brand image and brand awareness [65]. Chen et al. [66] developed and demonstrated a mediation-moderation model of airline service quality that influenced the repurchase intentions of passengers. They also studied the mediating influence of brand awareness on perceived value, and concluded that service quality is positively and indirectly related to perceived value through brand awareness. From the above discussion, we drew the following hypotheses.

Hypothesis 7 (H7). Sophisticated social media marketing activities (SSMMAs) (H7 (a) interaction, H7 (b) sharing, $H 7$ (c) trendiness) positively moderate the indirect relationship between fundamental SMMAs, apparel brand awareness, and apparel brand price premium willingness. 
Hypothesis 8 (H8). Sophisticated social media marketing activities (SSMMAs) (H8 (a) interaction, H8 (b) sharing, H8 (c) trendiness) positively moderate the indirect relationship between fundamental SMMAs, apparel brand awareness, and apparel brand customer loyalty.

Hypothesis 9 (H9). Sophisticated social media marketing activities (SSMMAs) (H9 (a) interaction, H9 (b) sharing, H9 (c) trendiness) positively moderate the indirect relationship between fundamental SMMAs, apparel brand image, and apparel brand price premium willingness.

Hypothesis 10 (H10). Sophisticated social media marketing activities (SSMMAs) (H10 (a) interaction, H10 (b) sharing, H10 (c) trendiness) positively moderate the indirect relationship between fundamental SMMAs, apparel brand image, and apparel brand customer loyalty.

\subsection{Methods}

Sample and Procedure

The quantitative approach was used to verify our proposed conceptual model. To research the proposed purpose, several steps were used in data collection. First, the extensive literature about SMMAs, brand equity, customer response, and well-known apparel/clothing brands in Pakistan was studied to formulate the original survey. Second, the measurement scales for proposed variables were carefully adapted from the previous study, as shown in Table 1. Furthermore, we revised some of the adapted questions to fit our proposed model. The categorical scale for all variables is divided into a five-point Likert scale, in which the responses vary from 5 (strongly agree) to 1 (strongly disagree). Third, the adapted questionnaire was converted to an online survey using the www.wjx.cn web service.

Table 1. Measurement Scales Used.

\footnotetext{
Social Media Marketing Activities [21,22]

Likes/followers/subscribers

(1) The X apparel brand that I followed has more 'likes $\backslash$ followers $\backslash$ subscribers' on social media.

(2) More 'likes $\backslash$ followers $\backslash$ subscribers' influence me to join $X$ apparel brand on social media.

(3) More 'likes $\backslash$ followers $\backslash$ subscribers' gives me a remarkable memory about $X$ apparel brand.

Interactions construct questions

(1) I will join X apparel brand's social media where a discussion and exchange of opinion are possible (mutual conversation).

(2) I will join $X$ apparel brand's social media where the exchange of opinion is easy.

(3) X apparel brand's social media platform enables information sharing with others.

(4) More and positive comments on $X$ apparel brand enable me to identify $X$ brand easily.

Sharing constructs questions

(1) The X apparel brand that I followed has more posts/tweets on social media.

(2) More posts/tweets about $X$ apparel brand enable me to identify $X$ brand easily.

(3) The X apparel brand that I followed has more links to/from other social media.

(4) More links to/from other social media about $X$ apparel brand increase its popularity.

Trendiness constructs questions

(1) The apparel brand that I followed has the latest information on social media.

(2) The latest information about $X$ apparel brand enables me to identify $X$ brand easily.

(3) The apparel brand that I followed has had trending information on social media.

(4) More trendy information about $X$ apparel brand enables me to identify the $X$ brand easily.

Brand Equity

Brand awareness [21,67]

(1) I am always aware of $X$ apparel brand through social media.

(2) X brand's social media enables me to keep X apparel brand characteristics in my mind.

(3) X brand's social media enables me to recall the symbol or logo of $\mathrm{X}$ apparel brand quickly.

Brand image $[21,67]$

(1) X apparel brand is customer-oriented on the social media platform.

(2) Social media enables me to keep an impressive memory of $X$ apparel brand.

(3) $\mathrm{X}$ brand is a leading apparel brand on social media.
} 
Table 1. Cont.

Customer Response

Price premium willingness [21,57]

(1) I am willing to pay a higher price for $X$ apparel brand than for other brands.

(2) The price of $X$ apparel brand would have to increase quite a bit before I would switch to other brands.

(3) I am willing to pay __ more for $X$ apparel brand than for other brands. $0 \%, 5 \%, 10 \%, 15 \%, 20 \%$

Customer loyalty [21]

(1) I will suggest $X$ apparel brand to others on social media.

(2) I will regularly visit $X$ apparel brand on social media.

(3) X apparel brand will be my first choice as compared to others.

(4) I am satisfied with $X$ apparel brand with every visit.

The targeted population of this study was Pakistani consumers (students, teachers, employees, businessmen, housewives, and others) who have followed apparel brands on social media. Pakistan was chosen for the study sample because of convenience, and since it is a developing country, where most of the people are using social media for entertainment and other social perspectives [14]. Secondly, the apparel and textile industry of Pakistan is very famous, and it is the eighth largest exporter of apparel brands in Asia [47]. For simplicity, we suggested well-known Pakistani apparel brands to the respondents, i.e., Gul Ahmad, Alkaram, Junaid Jamshid, Musarat Misbah, Maria B, and Khaadi in the questionnaire. Convenience sampling was used to select the participants. The online survey was sent to the participants through different social networks, i.e., WeChat, WhatsApp, imo, and Facebook. The data were collected from December 2018 to January 2019. Some screening questions (i.e., age $<18$, social media usage $<1$ hour, and non-followers of brands) were set to identify those respondents who are not among the target consumers and focus on regular users of social media as well as followers of apparel brands. There were a total of 455 participants; however, the final sample was composed of 406 usable responses from respondents, as 49 responses were disqualified since they did not follow any apparel brands. There were more females $(67.49 \%)$ than males (32.51\%). Most of the respondents $(75.4 \%)$ were aged between $20-35$. The majority of the respondents were university degree holders $(85.4 \%)$, while the rest of the respondents had obtained secondary education (14.4\%) and primary education $(0.2 \%)$.

\section{Empirical Results}

The collected data via the survey on apparel brands were analyzed using the SPSS 23.0 and AMOS 24.0 statistical programs. Before evaluating the hypotheses, a confirmatory factor analysis (CFA) procedure was applied to the measurement model validity test. Our hypotheses are mainly divided into mediation and moderated mediation effects. To test the mediation and moderated mediation impact, we used conditional process modeling (PROCESS macro) for SPSS [30]. PROCESS macro has been used in various studies recently published in prestigious journals [68,69]. PROCESS macro enabled us to conduct mediation (Hayes Model 4) and moderated mediation (Hayes Model 7) tests to assess the indirect effects of FSMMAs (likes, followers, viewers, subscribers) on customer response through the mediating mechanisms of brand equity at different levels of SSMMAs (interaction, sharing, trendiness).

\subsection{Reliability and Construct Validity}

The internal consistency of all variables is measured through Cronbach's alpha, as shown in Table 2. The construct validity of the key variables in this study is examined using CFA. To evaluate the CFA, we followed the guidelines of Chau [70,71]. The results of CFA for SMMAs, Brand Equity (BE), and Customers' Response (CR) is within the threshold limit [70]. The standardized loadings and average variance extracted (AVE) for all potential variables were over 0.5 , supporting the convergent validity of all the measurement variables. The goodness range (goodness-of-fit) in CFA of the proposed SMMAs, brand equity, and customer response is shown in Table 2. 
Table 2. Confirmatory Factor Analyses (CFA).

\begin{tabular}{|c|c|c|c|c|c|}
\hline & & Standardized Factor Loadings & CR & AVE & Alpha \\
\hline \multirow{7}{*}{ CR } & \multirow{3}{*}{ PP } & 0.903 & \multirow{3}{*}{0.93} & \multirow{3}{*}{0.81} & \multirow{3}{*}{0.93} \\
\hline & & 0.895 & & & \\
\hline & & 0.903 & & & \\
\hline & \multirow{4}{*}{ CL } & 0.878 & \multirow{4}{*}{0.94} & \multirow{4}{*}{0.78} & \multirow{4}{*}{0.91} \\
\hline & & 0.888 & & & \\
\hline & & 0.876 & & & \\
\hline & & 0.901 & & & \\
\hline
\end{tabular}

CFA Model goodness of fit indices

CFA model indices results, $\chi 2=45.618, d f=13, \mathrm{CMIN} / \chi 2=3.509, p=0.000, \mathrm{NFI}=0.984, \mathrm{TLI}=0.981$, $\mathrm{CFI}=0.989, \mathrm{GFI}=0.965, \mathrm{AGFI}=0.924, \mathrm{SRMR}=0.0137, \mathrm{RMSEA}=0.083$

\begin{tabular}{cccccc}
\hline \multirow{3}{*}{ BE } & BIM & 0.913 & & & \\
\cline { 3 - 3 } & & 0.913 & 0.94 & 0.85 & 0.92 \\
\cline { 3 - 3 } & \multirow{2}{*}{ BAW } & 0.937 & & & \\
\cline { 3 - 3 } & & 0.933 & 0.95 & 0.87 & 0.92 \\
& & 0.927 & & & \\
\hline
\end{tabular}

CFA Model goodness of fit indices

CFA model indices results $\chi 2=26.577, \mathrm{df}=8, \mathrm{CMIN} / \chi 2=3.322, p=0.001, \mathrm{NFI}=0.991, \mathrm{TLI}=0.988$, $\mathrm{CFI}=0.994, \mathrm{GFI}=0.975, \mathrm{AGFI}=0.934, \mathrm{SRMR}=0.0088, \mathrm{RMSEA}=0.080$

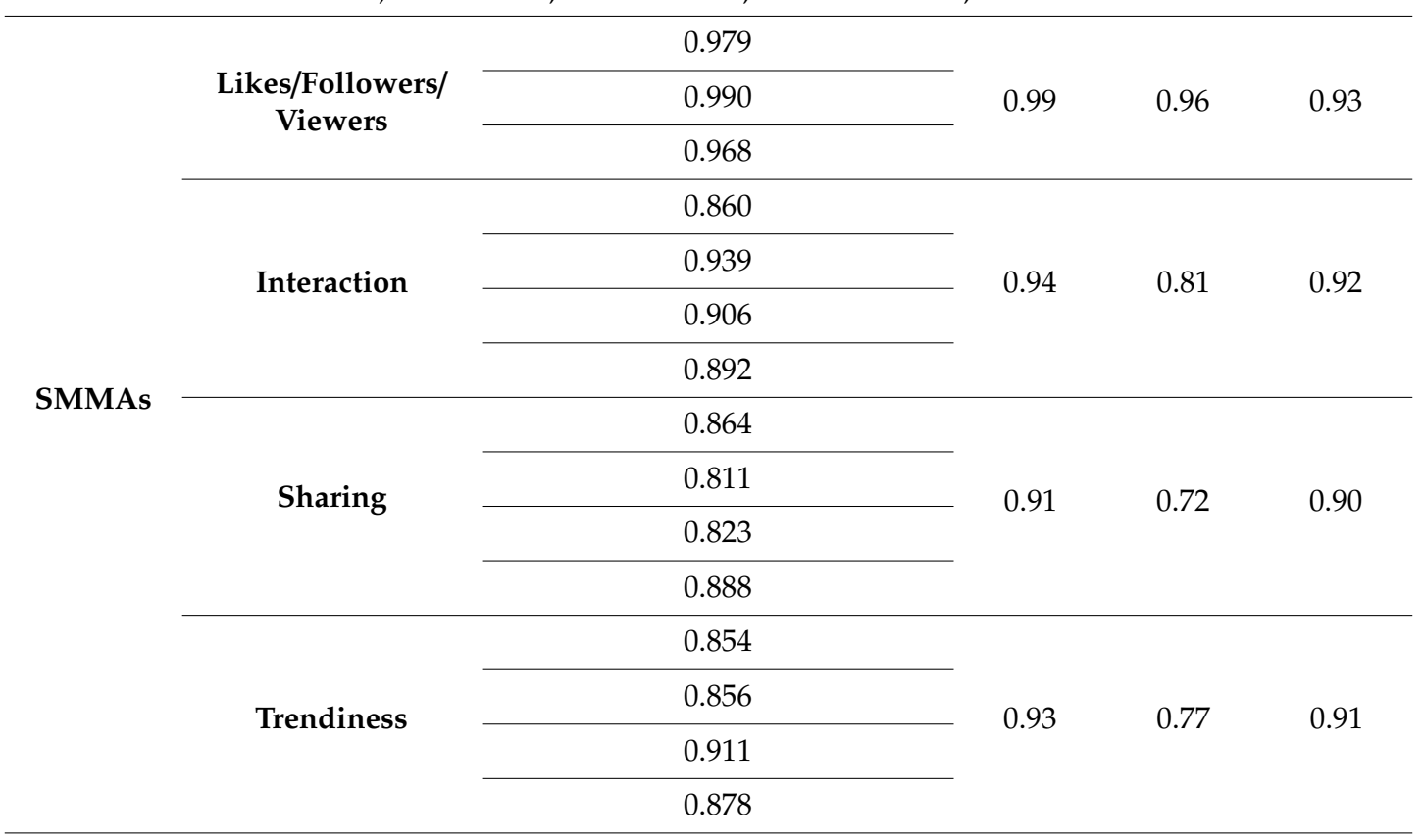

CFA Model goodness of fit indices

CFA Model indices results, $\chi 2=340.284, \mathrm{df}=75, \mathrm{CMIN} / \chi 2=4.537, p=0.000, \mathrm{NFI}=0.956, \mathrm{TLI}=0.951$, $\mathrm{CFI}=0.965, \mathrm{GFI}=0.904, \mathrm{AGFI}=0.847, \mathrm{SRMR}=0.0282, \mathrm{RMSEA}=0.099$

* Notes: AVE: Average Variance Extracted, CR: Customer Response, PP: Price Premium, CL: Customer Loyalty, BE: Brand Equity, BAW: Brand Awareness, BIM: Brand Image, SMMAs: Social Media Marketing Activities, Alpha: Cronbach's Alpha (Reliability/Internal Consistency). 


\subsection{Discriminant Validity}

In this section, discriminant validity is assessed using the Fornell-Larcker criterion [72]. Here, the square root of average variance extracted (AVE) and the correlation of the respective constructs are compared. The correlation analysis indicates that square roots of all AVE (ranging from 0.88 to 0.98 ) were greater than the off-diagonal correlation (ranging from 0.217 to 0.852 ) for each corresponding construct. We also used the approach of Ngo and O'Cass [73] to confirm the discriminant validity further and determine that the correlation between any two constructs was less than their respective composite reliability (ranging from 0.91 to 0.99 ). In a nutshell, the findings in Table 3 suggest sufficient discriminant validity.

Table 3. Correlation and Discriminant Validity.

\begin{tabular}{ccccccccc}
\hline & PP & CL & BIM & BAW & Likes & Int & Sh & Tre \\
\hline PP & 0.9 & & & & & & & \\
\hline CL & $0.635^{* *}$ & 0.88 & & & & & & \\
\hline BIM & $0.717^{* *}$ & $0.751^{* *}$ & 0.92 & & & & & \\
\hline BAW & $0.602^{* *}$ & $0.737^{* *}$ & $0.852^{* *}$ & 0.93 & & & \\
\hline Likes & $0.462^{* *}$ & $0.454^{* *}$ & $0.522^{* *}$ & $0.497^{* *}$ & 0.98 & & \\
\hline Int & $0.660^{* *}$ & $0.693^{* *}$ & $0.788^{* *}$ & $0.836^{* *}$ & $0.254^{* *}$ & 0.90 & & \\
\hline Sh & $0.631^{* *}$ & $0.673^{* *}$ & $0.776^{* *}$ & $0.792^{* *}$ & $0.217^{* *}$ & $0.750^{* *}$ & 0.85 & \\
\hline Tre & $0.661^{* *}$ & $0.699^{* *}$ & $0.795^{* *}$ & $0.724^{* *}$ & $0.224^{* *}$ & $0.642^{* *}$ & $0.749^{* *}$ & 0.88 \\
\hline
\end{tabular}

* Notes: PP: Price Premium, CL: Customer Loyalty, BAW: Brand Awareness, BIM: Brand Image, Int: Interaction, Sh: Sharing, Tre: Trendiness.

\subsection{Testing of Hypothesized Direct and Indirect Effects}

Hypotheses H1 to H6 are evaluated with the help of a simple mediation model (Model 4) [30] in SPSS. $\mathrm{H} 1$ and $\mathrm{H} 2$ represent the direct influence of FSMMAs over customer response. Figure $2 \mathrm{~b}, \mathrm{c}$ shows that FSMMAs have a positive direct effect on customer response in the context of price premium willingness $(\alpha 1$ (brand awareness as a mediator) $=0.1551, \alpha 2$ (brand image as a mediator) $=0.1570$, $p<0.05$ ). The same association is also held in the context of customer loyalty ( $\alpha 3$ (brand awareness as a mediator) $=0.1284, \alpha 4$ (brand image as a mediator) $=0.1338, p<0.05$ ), as shown in Figure $2 \mathrm{~b}$,c . Here, alphas $(\alpha 1, \alpha 2, \alpha 3, \alpha 4)$ are the coefficients showing the strength of the relationship among FSMMAs, price premium willingness, and customer loyalty. The findings in Figure $2 b, c$ support $\mathrm{H} 1$ and H2. The empirical results also indicate that FSMMAs' influence over price premium willingness is greater than that of customer response.

To evaluate the existence of mediation, we used bias-corrected bootstrapping on the recommendations of $[30,74]$ to examine the true indirect effects of FSMMAs on customer response via brand equity. The indirect effect of FSMMAs on price premium willingness via brand awareness (BAW) $(a b=0.1418)$ and brand image $(B I M)(a b=0.1398)$ were entirely above zero (BAW: $95 \%$ Confidence Interval (CI) lower limit (LL): 0.1019 and upper limit (UL): 0.1870, BIM: 95\% CI lower limit (LL): 0.1013 and upper limit (UL): 0.1845). Since both of the effects are significant at $p<0.05$ (no zero included in the $95 \% \mathrm{CI}$ ), hence $\mathrm{H} 3$ and $\mathrm{H} 5$ are supported. The results of the bootstrapping analysis are presented in Table 4 in detail. Similarly, the indirect effect of FSMMAs on customer loyalty via BAW and BIM belongs to the acceptable threshold (zero is not included in the 95\% CI), as shown in Table 4. Hence, $\mathrm{H} 4$ and $\mathrm{H} 6$ are supported. 
Total effect

(a)

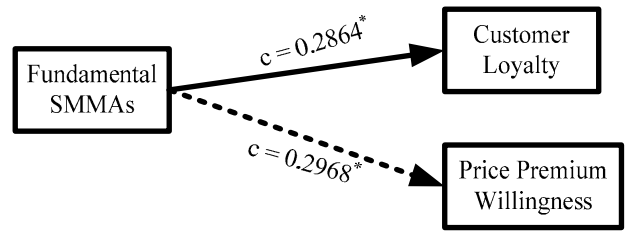

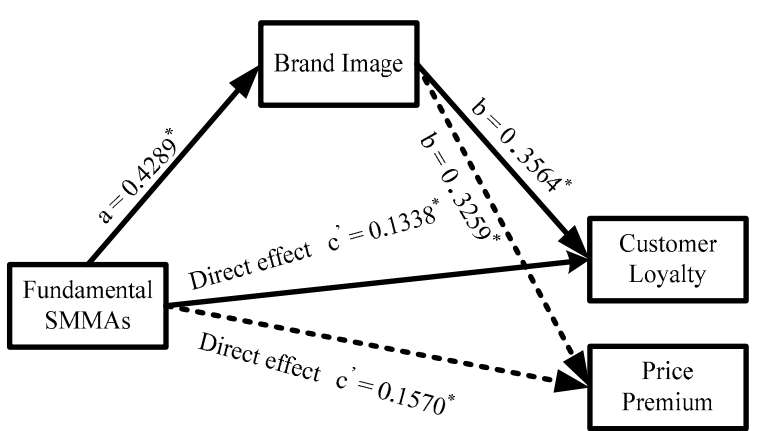

(b)

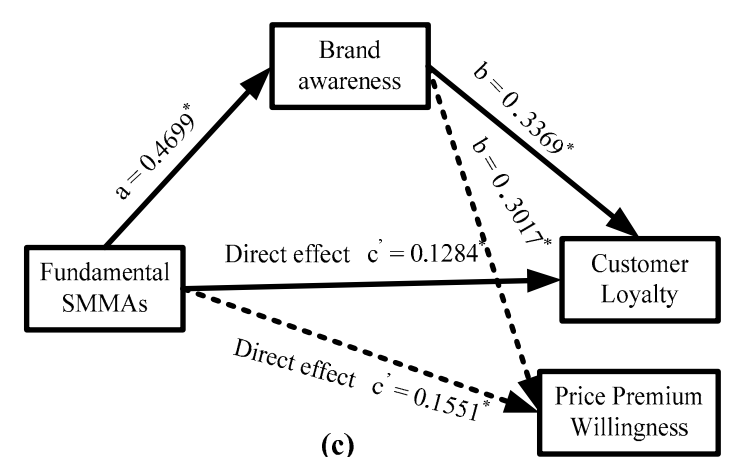

(c)

Figure 2. Simple Mediation Using PROCESS macro (Model 4), Direct and Indirect Relationships between Fundamental SMMAs and Price Premium Willingness. (a) Total effect, (b) Brand image as mediator case, (c) Brand awareness as mediator case. Note: ${ }^{*}$ represents the direct effect.

Table 4. Indirect Effects of FSMMAs on Customer Response (Price Premium and Customer Loyalty) through Brand Equity (Brand Awareness and Brand Image).

\begin{tabular}{|c|c|c|c|c|c|c|c|c|}
\hline Output (Y) & Mediator & Model & B & SE & $t$ & $p$ & LLCI & ULCI \\
\hline \multirow{10}{*}{ PP } & \multirow{5}{*}{ BAW } & FSMMAs $\rightarrow$ BAW (path a) & 0.4699 & 0.0408 & \multirow{5}{*}{$\begin{array}{l}11.529 \\
8.5455 \\
9.9252 \\
4.8540\end{array}$} & \multirow{5}{*}{$\begin{array}{l}0.0000 \\
0.0000 \\
0.0000 \\
0.0000\end{array}$} & 0.3898 & 0.5501 \\
\hline & & $\mathrm{BAW} \rightarrow \mathrm{PP}$ (path b) & 0.3017 & 0.0353 & & & 0.2323 & 0.3711 \\
\hline & & FSMMAs $\rightarrow$ PP (path c) & 0.2968 & 0.0299 & & & 0.2380 & 0.3556 \\
\hline & & FSMMAs $\rightarrow$ PP (path c') & 0.1551 & 0.0319 & & & 0.0922 & 0.2179 \\
\hline & & Indirect Effect of BAW & 0.1418 & 0.0212 & & & 0.1019 & 0.1870 \\
\hline & \multirow{5}{*}{ BIM } & FSMMAs $\rightarrow$ BIM (path a) & 0.4289 & 0.0382 & \multirow{5}{*}{$\begin{array}{l}11.239 \\
8.6648 \\
9.9252 \\
4.9609\end{array}$} & \multirow{5}{*}{$\begin{array}{l}0.0000 \\
0.0000 \\
0.0000 \\
0.0000\end{array}$} & 0.3538 & 0.5039 \\
\hline & & $\mathrm{BIM} \rightarrow \mathrm{PP}$ (path b) & 0.3259 & 0.0376 & & & 0.2520 & 0.3999 \\
\hline & & FSMMAs $\rightarrow$ PP (path c) & 0.2968 & 0.0299 & & & 0.2380 & 0.3556 \\
\hline & & FSMMAs $\rightarrow$ PP (path c') & 0.1570 & 0.0317 & & & 0.0948 & 0.2193 \\
\hline & & Indirect Effect of BIM & 0.1398 & 0.0213 & & & 0.1013 & 0.1845 \\
\hline \multirow{10}{*}{ CL } & \multirow{6}{*}{ BAW } & FSMMAs $\rightarrow$ BAW (path a) & 0.4699 & 0.0408 & \multirow{5}{*}{$\begin{array}{l}11.529 \\
9.9847 \\
9.7339 \\
4.2047\end{array}$} & \multirow{5}{*}{$\begin{array}{l}0.0000 \\
0.0000 \\
0.0000 \\
0.0000\end{array}$} & 0.3898 & 0.5501 \\
\hline & & BAW $\rightarrow$ CL (path b) & 0.3369 & 0.0337 & & & 0.2705 & 0.4032 \\
\hline & & FSMMAs $\rightarrow$ CL (path c) & 0.2867 & 0.0295 & & & 0.2288 & 0.3446 \\
\hline & & FSMMAs $\rightarrow$ CL (path c') & 0.1284 & 0.0305 & & & 0.0683 & 0.1884 \\
\hline & & Indirect Effect of BAW & 0.1583 & 0.0216 & & & 0.1187 & 0.2036 \\
\hline & & FSMMAs $\rightarrow$ BIM (path a) & 0.4289 & 0.0382 & \multirow{5}{*}{$\begin{array}{l}11.239 \\
9.8654 \\
9.7339 \\
4.4011\end{array}$} & \multirow{5}{*}{$\begin{array}{l}0.0000 \\
0.0000 \\
0.0000 \\
0.0000\end{array}$} & 0.3538 & 0.5039 \\
\hline & \multirow{4}{*}{ BIM } & $\mathrm{BIM} \rightarrow \mathrm{CL}$ (path b) & 0.3564 & 0.0361 & & & 0.2854 & 0.4275 \\
\hline & & FSMMAs $\rightarrow$ CL (path c) & 0.2867 & 0.0295 & & & 0.2288 & 0.3446 \\
\hline & & FSMMAs $\rightarrow$ CL (path c') & 0.1338 & 0.0304 & & & 0.0740 & 0.1936 \\
\hline & & Indirect Effect of BIM & 0.1529 & 0.0224 & & & 0.1126 & 0.1998 \\
\hline
\end{tabular}

* Note: BAW: Brand Awareness, BIM: Brand Image, LLCI: Lower Level Confidence Interval, ULCI: Upper Level

Confidence Interval, PP: Price Premium, CL: Customer Loyalty. 


\subsection{Assessment of the Moderated Mediation Effects}

In our model, it is proposed that SSMMAs moderate the relationship between FSMMAs and mediators (BAW, BIM). The constructs to measure SSMMAs in this study are shown in Figure 1. Hypotheses H7 (a, b, c) to H10 (a, b, c) demonstrate a moderated mediation effect. The hypotheses mentioned above were tested with a conditional process analysis (Model 7) following the PROCESS macro $[30,74]$, where the strength of the indirect association between FSMMAs and customer response is measured at different values of the moderator, i.e., SSMMAs. The model allows all possible direct and indirect effects between independent and outcome variables to be moderated by SSMMAs, as shown in Figure 3. The SSMMAs such as interactions, sharing, and trendiness were considered individually independent moderators over mediated association. This study employed 5000 bootstrap samples to obtain estimates for the conditional relationships. The coefficient values (B), i.e., b1, b2, and b3 show the moderating effects of interactions, sharing, and trendiness, respectively in Figure 3.
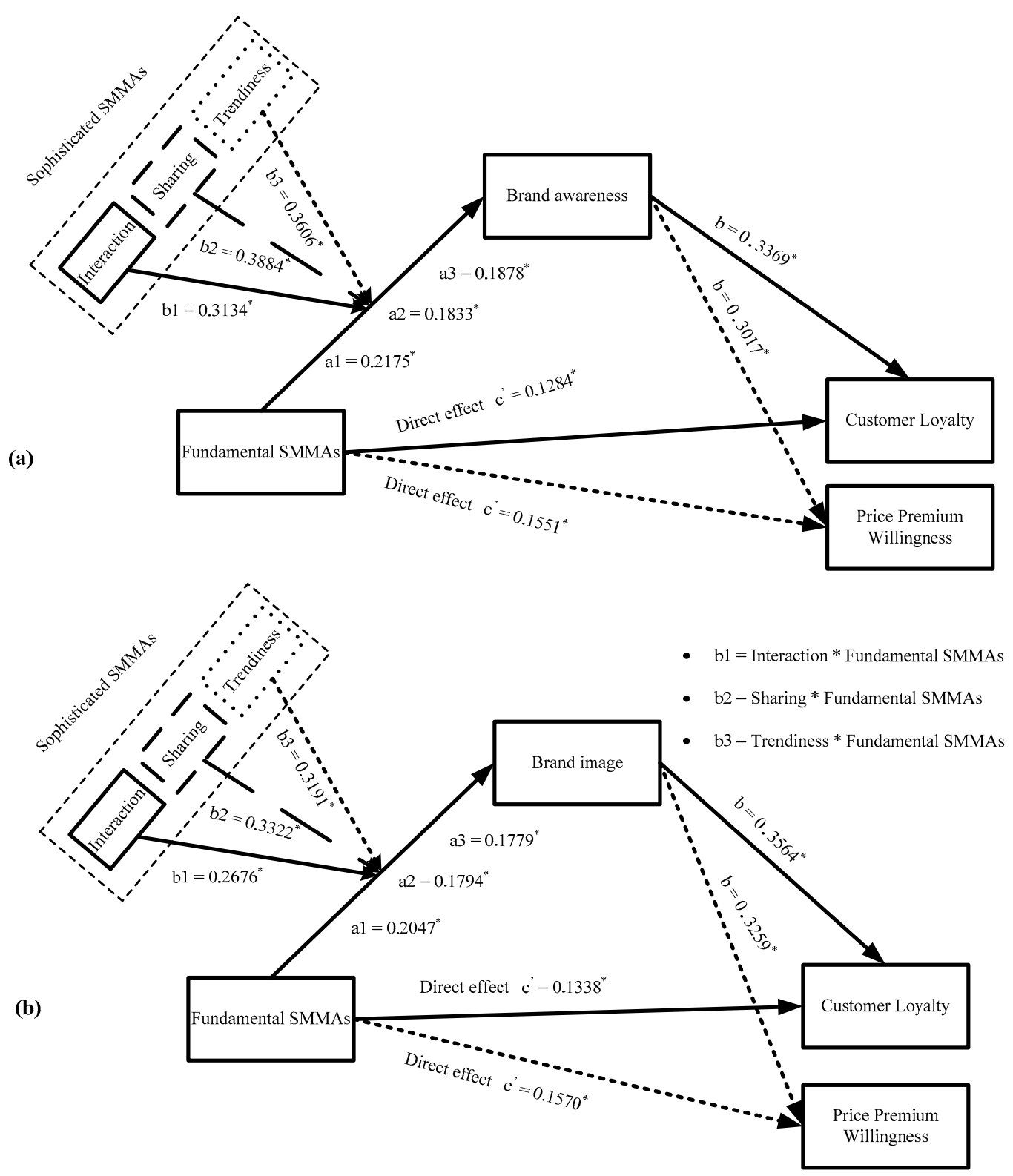

Figure 3. Conditional effects of sophisticated SMMAs on the relationship of fundamental SMMAs and price premium via brand equity (brand awareness and brand image); (a) Brand awareness as a mediator, (b) Brand image as a mediator. All statistical results are significant at $p<0.05$. 
On the recommendation of $[30,74]$, we assessed the statistical significance of the conditional indirect effect at two values of the moderators, i.e., 1 and 0 (see Table 5). These values correspond to the presence $($ Strongly Agree $=$ Agree $=1)$ and absence $($ Undecided $=$ Disagree $=$ Strongly Disagree $=0)$ effects of the moderators. Table 5 shows that the indirect effects of FSMMAs $(\mathrm{X})$ on price premium willingness (Y1) and customer loyalty (Y2) via brand awareness and brand image are positive and increase with SSMMAs. A bias-corrected bootstrap using 5000 resamples found that the conditional indirect effect of FSMMAs on price premium willingness through brand awareness was highly significant at value 1 for $W=$ Interaction (bootstrapped indirect effect $=0.1601 ; 95 \%$ CI 0.1189 to 0.2051 ), and also significant at zero for interaction activity (bootstrapped indirect effect $=0.0656 ; 95 \%$ CI 0.0365 to 0.0981 ). The trendiness (bootstrapped indirect effect $=0.1725 ; 95 \% \mathrm{CI} 0.1268$ to 0.2208 at $\mathrm{W}=1$ and $p<0.05$ ) and sharing (bootstrapped indirect effect $=0.1654 ; 95 \% \mathrm{CI} 0.1225$ to 0.2116 at $\mathrm{W}=1$ and $p<0.05$ ) also moderate the mediated relationship of FSMMAs, brand awareness, and price premium willingness.

Table 5. Conditional Indirect Effects of Fundamental SMMAs on Customer Response via Brand Equity at Different Values of Sophisticated SMMAs as Moderator.

\begin{tabular}{|c|c|c|c|c|c|}
\hline \multirow{2}{*}{$\begin{array}{l}\text { X (FSMMAs) } \\
\text { Mediator (M) }\end{array}$} & \multirow{2}{*}{$\begin{array}{c}\text { Y1 (PP) } \\
\text { Moderator }(\mathrm{W})=\text { Interaction }\end{array}$} & \multicolumn{4}{|c|}{ Bias-Corrected Bootstrap 95\% CI } \\
\hline & & Indirect effect & Boot SE & LL & UL \\
\hline \multirow{2}{*}{ BAW } & 1 & 0.1601 & 0.0217 & 0.1189 & 0.2051 \\
\hline & 0 & 0.0656 & 0.0158 & 0.0365 & 0.0981 \\
\hline \multirow{3}{*}{ BIM } & 1 & 0.1540 & 0.0203 & 0.1171 & 0.1967 \\
\hline & 0 & 0.0667 & 0.0187 & 0.0339 & 0.1057 \\
\hline & Moderator $(W)=$ Sharing & Indirect effect & Boot SE & LL & UL \\
\hline \multirow[t]{2}{*}{ BAW } & 1 & 0.1725 & 0.0237 & 0.1268 & 0.2208 \\
\hline & 0 & 0.0553 & 0.0142 & 0.0302 & 0.0860 \\
\hline \multirow{3}{*}{ BIM } & 1 & 0.1668 & 0.0221 & 0.1258 & 0.2119 \\
\hline & 0 & 0.0585 & 0.0177 & 0.0264 & 0.0968 \\
\hline & Moderator $(W)=$ Trendiness & Indirect effect & Boot SE & LL & UL \\
\hline \multirow[t]{2}{*}{ BAW } & 1 & 0.1654 & 0.0225 & 0.1225 & 0.2116 \\
\hline & 0 & 0.0567 & 0.0142 & 0.0308 & 0.0869 \\
\hline \multirow{2}{*}{ BIM } & 1 & 0.1620 & 0.0215 & 0.1224 & 0.2073 \\
\hline & 0 & 0.0580 & 0.0172 & 0.0277 & 0.0945 \\
\hline X (FSMMAs) & Y1 (CL) & \multicolumn{4}{|c|}{ Bias-Corrected Bootstrap 95\% CI } \\
\hline Mediator (M) & Moderator $(W)=$ Interaction & Indirect effect & Boot SE & LL & UL \\
\hline \multirow{3}{*}{ BAW } & 1 & 0.1788 & 0.0216 & 0.1380 & 0.2229 \\
\hline & 0 & 0.0733 & 0.0174 & 0.0410 & 0.1112 \\
\hline & 1 & 0.1684 & 0.0212 & 0.1301 & 0.2143 \\
\hline \multirow[t]{2}{*}{ BIM } & 0 & 0.1684 & 0.0212 & 0.1301 & 0.2143 \\
\hline & Moderator $(\mathrm{W})=$ Sharing & Indirect effect & Boot SE & LL & UL \\
\hline \multirow{3}{*}{ BAW } & 1 & 0.1926 & 0.0236 & 0.1485 & 0.2404 \\
\hline & 0 & 0.0618 & 0.0152 & 0.0334 & 0.0929 \\
\hline & 1 & 0.1824 & 0.0235 & 0.1398 & 0.2313 \\
\hline \multirow[t]{3}{*}{ BIM } & 0 & 0.0640 & 0.0195 & 0.0286 & 0.1057 \\
\hline & Moderator $(\mathrm{W})=$ Trendiness & Indirect effect & Boot SE & LL & UL \\
\hline & 1 & 0.1847 & 0.0223 & 0.1438 & 0.2310 \\
\hline \multirow[t]{2}{*}{ BAW } & 0 & 0.0633 & 0.0157 & 0.0340 & 0.0963 \\
\hline & 1 & 0.1772 & 0.0224 & 0.1357 & 0.2232 \\
\hline BIM & 0 & 0.0634 & 0.0188 & 0.0301 & 0.1035 \\
\hline
\end{tabular}

This result supports H7 (a, b, c). Similarly, the bootstrap results in Table 5 found that the conditional indirect effect of independent variable and price premium willingness via brand image were significant for interactions (bootstrapped indirect effect $=0.1540 ; 95 \%$ CI 0.01171 to 0.1967 at $\mathrm{W}=1$ and $p<0.05$ ), 
sharing (bootstrapped indirect effect $=0.1668 ; 95 \%$ CI 0.1258 to 0.2119 at $\mathrm{W}=1$ and $p<0.05$ ), and trendiness (bootstrapped indirect effect $=0.1620 ; 95 \%$ CI 0.1224 to 0.2073 at $\mathrm{W}=1$ and $p<0.05$ ), which confirmed H9 $(\mathrm{a}, \mathrm{b}, \mathrm{c})$. The bias-corrected 95\% CIs for the conditional indirect effect are above zero for all levels of the moderators as shown in Table 5, and thus H8 (a, b, c) and H10 $(a, b, c)$ are significant.

To determine the importance of each dimension, we further analyzed the descriptive statistics in SPSS for each SSMMA component. Concerning the 'interaction' component, it is noticed from descriptive statistics that opinion sharing (69\%) was more important than mutual sharing (69\%). Secondly, the number of posts/tweets ( $68 \%$ responses in favor) dimension of the 'sharing' component was more important than the number of links to/from dimension (67\% responses in favor). Lastly, the descriptive statistics disclosed that trendiest information ( $70 \%$ responses in favor) dimension of the 'trendiness' component was more important than the latest information dimension ( $67 \%$ responses in favor).

\section{Discussion and Practical Implications}

The importance of SMMAs has been thoroughly discussed theoretically and practically in an increasing number of research studies for brand building [21-23,51,66]. However, still, many gaps exist, and many researchers are struggling to find empirical results of how SMMAs influence brand equity in different industries. Furthermore, the impact of brand equity over other branding goals (brand loyalty, preference, and price premium willingness) is also the main focus of many authors. Due to numerous conceptual and measurement issues, social media marketing is a big challenge for a company to attract potential customers. The strategic and innovative use of SMMAs is the primary concern to positively influence the brand equity and customer response toward the brand [75]. The apparel brands in Pakistan are the basis of this study because most of the previous work pointed out that fashion brands (especially luxury brands) are mostly attracting their customers via an active use of social media $[13,21,22,47,76]$. Although this study assessed Pakistani consumer attitudes toward social media marketing; however, they can be in line with those of consumers in other developing countries, and will have the same implications over there as well.

Although the previous study determined the importance of different SMMAs [21-23,66,76], our conceptual model subdivided the activities into two groups and concluded that both sets should be considered entirely when planning social media marketing strategies. We considered the most active social media, i.e., Facebook, Twitter, and YouTube, but we investigated the overall impact instead of individual platform effect. Since $89 \%$ of our respondents were Facebook users, it can be determined that the apparel brands should focus on Facebook-based advertisements in Pakistan.

In the literature $[21-23,66,76]$, it was found that SMMAs have a significant positive impact on brand equity (i.e., brand awareness and image). Here, in our case, the FSMMAs (Facebook likes, Twitter followers, and YouTube viewers) positively influence the two dimensions of brand equity: brand awareness and brand image. Moreover, the SSMMAs (interactions, sharing, and trendiness) subsequently moderate the relationship between FSMMAs and brand equity dimensions. Hence, we can say that SSMMAs and FSMMAs can be used as essential brand image-building tools, as well as sources for reaching new customers. Moreover, it is also determined that the sharing and trendiness components are essential for enhancing the awareness and image of a brand. The apparel brands should focus on the sharing of brand-related trendy information to enhance business sustainability.

The authors Godey et al. [21] showed that brand equity partially mediates the relationship between SMMAs and customer response. Our results are not only consistent with the previous work, but we also identified that SSMMAs positively moderate the partially mediated relationship among FSMMAs, brand equity, and customer response. These results suggest that a company should invest more on brand equity and an innovative use of SMMAs (especially SSMMAs) to get a good response from the customer side in term of price premium willingness and loyalty. The results demonstrate that FSMMAs have significant positive direct and indirect (via brand equity) effects on price premium willingness and customer response. It is noted that opinion sharing about a specific apparel brand on social media 
is significantly essential to increase the awareness and image of that brand. Similarly, the number of posts/tweets and trendiest information dimensions of 'sharing' and 'trendiness' respectively are essential to increase customer response (via brand equity) in terms of price premium willingness and customer response. Similarly, our results are also in line with other studies related to the influence of social media marketing on brand equity and customer response in different industries $[23,66]$. Furthermore, the price premium willingness depends on brand preference, which is another necessary consequence. Both components are essential in the literature, which is not discussed much in the social media context [21]. Therefore, SMMAs have the latent power to participate in business sustainability in term of branding goals in the same way as conventional marketing activities.

\section{Conclusions, Limitations, and Future Directions}

This study investigated the impacts of SMMAs (Facebook, Twitter, YouTube) on apparel brand equity (i.e., brand awareness, image) and two types of customer response (price premium willingness, customer loyalty), aiming to enhance business sustainability. Here, first, the existing SMMAs are subdivided into two novel sets, i.e., FSMMAs and SSMMAs. The results of this study are summarized as follows. First, FSMMAs had positive direct effects on price premium willingness and customer loyalty, confirming that Facebook likes, Twitter followers, and YouTube viewers and subscribers are contributing to apparel brands. Second, brand equity (i.e., brand awareness and image) had significantly mediated the effects of FSMMAs and (price premium willingness and customer loyalty), which shows the importance of brand equity. Hence, an apparel brand should focus on their brand's awareness and image on social media to attract and retain their customers. Third, SSMMAs had moderated the mediation effect of FSMMAs, brand equity, and customer response. This confirmed that the advanced innovative use of social media marketing in terms of interactions, sharing, and trendiness could be used to improve brand awareness, brand image, price premium willingness, and customer loyalty. It is also concluded that SSMMAs are significant moderators to strengthen the relationship between FSMMAs and brand equity. An apparel brand should not only focus on FSMMAs components, but should also consider SSMMAs to gain more success in the market.

The limitations of this study along with future recommendations are as follows. First, the sample for this study was limited only to Pakistani customers. For more comprehensive results, this study will be adopted in the cross-culture of two countries. Here, we considered three social media channels (Facebook, Twitter, and YouTube), and measured the overall effect instead of the individual effect of each selected social media. This study can be extended by measuring the effect of our proposed SMMAs on individual social media. In this way, an apparel brand will be able to focus on which social media can attract more customers toward their brands. Although this study concluded that FSMMAs and SSMMAs had a positive influence on customer response, the concerns of these impacts on the managerial success of companies were not addressed.

Author Contributions: Z.K. proposed the whole idea and wrote the paper; Y.Y. reviewed and improved the quality of the manuscript. M.S. has helped in data analysis and proofreading the manuscript. R.Y. has done the final editing of the paper.

Funding: We gratefully acknowledge the research funding received from the Key Project of the National Social Science Fund (18AGL024).

Conflicts of Interest: The authors declare no conflict of interest.

\section{References}

1. Bento, M.; Martinez, L.M.; Martinez, L.F. Brand engagement and search for brands on social media: Comparing Generations X and Y in Portugal. J. Retail. Consum. Serv. 2018, 43, 234-241. [CrossRef]

2. Muralidharan, S.; Men, L.R. How peer communication and engagement motivations influence social media shopping behavior: Evidence from China and the United States. Cyberpsychol. Behav. Soc. Netw. 2015, 18, 595-601. [CrossRef] [PubMed] 
3. Gallaugher, J.; Ransbotham, S. Social media and customer dialog management at Starbucks. MIS Q. Exec. 2010, 9, 197-212.

4. Alalwan, A.A.; Rana, N.P.; Dwivedi, Y.K.; Algharabat, R. Social media in marketing: A review and analysis of the existing literature. Telemat. Inform. 2017, 34, 1177-1190. [CrossRef]

5. Kang, M.; Park, B. Sustainable corporate social media marketing based on message structural features: Firm size plays a significant role as a moderator. Sustainability 2018, 10, 1167. [CrossRef]

6. Wang, Y.; Chowdhury Ahmed, S.; Deng, S.; Wang, H. Success of Social Media Marketing Efforts in Retaining Sustainable Online Consumers: An Empirical Analysis on the Online Fashion Retail Market. Sustainability 2019, 11, 3596. [CrossRef]

7. Correa, T.; Hinsley, A.W.; De Zuniga, H.G. Who interacts on the Web? The intersection of users' personality and social media use. Comput. Hum. Behav. 2010, 26, 247-253. [CrossRef]

8. Shareef, M.A.; Mukerji, B.; Dwivedi, Y.K.; Rana, N.P.; Islam, R. Social media marketing: Comparative effect of advertisement sources. J. Retail. Consum. Serv. 2019, 46, 58-69. [CrossRef]

9. Vafaei, S.; Görgényi-Hegyes, É.; Fekete-Farkas, M. The Role of Social Media and Marketing in Building Sustainability Orientation. Available online: https://www.researchgate.net/publication/312473417_The_Role_ of_Social_Media_and_Marketing_in_Building_Sustainability_Orientation (accessed on 19 September 2019).

10. Jung, A.-R. The influence of perceived ad relevance on social media advertising: An empirical examination of a mediating role of privacy concern. Comput. Hum. Behav. 2017, 70, 303-309. [CrossRef]

11. Kim, A.J.; Johnson, K.K. Power of consumers using social media: Examining the influences of brand-related user-generated content on Facebook. Comput. Hum. Behav. 2016, 58, 98-108. [CrossRef]

12. InternetWorldStats. World Internet Usage and Population Statistics. 2019. Available online: www. internetworldstats.com/stats.htm (accessed on 2 June 2019).

13. Husnain, M.; Toor, A. The impact of social Network marketing on consumer purchase intention in Pakistan: Consumer engagement as a mediator. Asian J. Bus. Account. 2017, 10, 167-199.

14. StatCounter. StatCounter Global Stats: Search Engine. 2019. Available online: http://gs.statcounter.com/ social-media-stats/all/pakistan (accessed on 15 January 2019).

15. Schultz, C.D. Insights from consumer interactions on a social networking site: Findings from six apparel retail brands. Electron. Mark. 2016, 26, 203-217. [CrossRef]

16. Schultz, D.E.; Block, M.P. Rethinking brand loyalty in an age of interactivity. IUP J. Brand Manag. 2012, 9, 21.

17. Shareef, M.A.; Mukerji, B.; Alryalat, M.A.A.; Wright, A.; Dwivedi, Y.K. Advertisements on Facebook: Identifying the persuasive elements in the development of positive attitudes in consumers. J. Retail. Consum. Serv. 2018, 43, 258-268. [CrossRef]

18. Kamboj, S.; Sarmah, B.; Gupta, S.; Dwivedi, Y. Examining branding co-creation in brand communities on social media: Applying the paradigm of Stimulus-Organism-Response. Int. J. Inf. Manag. 2018, 39, 169-185. [CrossRef]

19. Schultz, D.E.; Peltier, J. Social media's slippery slope: Challenges, opportunities and future research directions. J. Res. Interact. Mark. 2013, 7, 86-99. [CrossRef]

20. Hollebeek, L.D.; Glynn, M.S.; Brodie, R.J. Consumer brand engagement in social media: Conceptualization, scale development and validation. J. Interact. Mark. 2014, 28, 149-165. [CrossRef]

21. Godey, B.; Manthiou, A.; Pederzoli, D.; Rokka, J.; Aiello, G.; Donvito, R.; Singh, R. Social media marketing efforts of luxury brands: Influence on brand equity and consumer behavior. J. Bus. Res. 2016, 69, 5833-5841. [CrossRef]

22. Kim, A.J.; Ko, E. Do social media marketing activities enhance customer equity? An empirical study of luxury fashion brand. J. Bus. Res. 2012, 65, 1480-1486. [CrossRef]

23. Seo, E.-J.; Park, J.-W. A study on the effects of social media marketing activities on brand equity and customer response in the airline industry. J. Air Transp. Manag. 2018, 66, 36-41. [CrossRef]

24. Chevalier, M.; Gutsatz, M. Luxury Retail Management: How the World's Top Brands Provide Quality Product and Service Support; John Wiley \& Sons: Hoboken, NJ, USA, 2012.

25. Bilal, G.; Ahmed, M.A.; Shehzad, M. Role of social media and social networks in consumer decision making: A case of the garment sector. Int. J. Multidiscip. Sci. Eng. 2014, 5, 1-9.

26. Shabbir, M.S.; Ghazi, M.S.; Mehmood, A.R. Impact of social media applications on small business entrepreneurs. Manag. Econ. Res. J. 2017, 2, 605. [CrossRef] 
27. Talat, A.; Azar, S.; Yousaf, M.W. Investigating social commerce as an alternate model for online commerce in developing countries: A case of Pakistani economy. Pak. J. Commer. Soc. Sci. (PJCSS) 2013, 7, 223-242.

28. Dahana, W.D.; Miwa, Y.; Morisada, M. Linking lifestyle to customer lifetime value: An exploratory study in an online fashion retail market. J. Bus. Res. 2019, 99, 319-331. [CrossRef]

29. Soomro, Y.A. Antecedents of brand loyalty in the fashion industry of Pakistan: Moderating effect of Individual-level collectivist values. MPRA 2019, 6, 33-46.

30. Hayes, A.F. Introduction to Mediation, Moderation, and Conditional Process Analysis: A Regression-Based Approach; Guilford Publications: New York, NY, USA, 2017.

31. Katz, E.; Blumler, J.G.; Gurevitch, M. The Uses of Mass Communications: Current Perspectives on Gratifications Research; Sage Publications: Thousand Oaks, CA, USA, 1974.

32. Ngai, E.W.; Tao, S.S.; Moon, K.K. Social media research: Theories, constructs, and conceptual frameworks. Int. J. Inf. Manag. 2015, 35, 33-44. [CrossRef]

33. Dahl, S. Social Media Marketing: Theories and Applications; Sage Publications: Thousand Oaks, CA, USA, 2018.

34. Lee, C.S.; Ma, L. News sharing in social media: The effect of gratifications and prior experience. Comput. Hum. Behav. 2012, 28, 331-339. [CrossRef]

35. Bolton, R.N.; Parasuraman, A.; Hoefnagels, A.; Migchels, N.; Kabadayi, S.; Gruber, T.; Komarova Loureiro, Y.; Solnet, D. Understanding Generation $\mathrm{Y}$ and their use of social media: A review and research agenda. J. Serv. Manag. 2013, 24, 245-267. [CrossRef]

36. Khan, M.L. Social media engagement: What motivates user participation and consumption on YouTube? Comput. Hum. Behav. 2017, 66, 236-247. [CrossRef]

37. Wang, M.-H.; Yang, T.-Y.; Chen, Y.-S. How workers engage in social networking sites at work: A uses and gratification expectancy perspective. Int. J. Organ. Innov. 2016, 8, 161-176.

38. De Oliveira, M.J.; Huertas, M.K.Z.; Lin, Z. Factors driving young users' engagement with Facebook: Evidence from Brazil. Comput. Hum. Behav. 2016, 54, 54-61. [CrossRef]

39. De Vries, N.J.; Carlson, J. Examining the drivers and brand performance implications of customer engagement with brands in the social media environment. J. Brand Manag. 2014, 21, 495-515. [CrossRef]

40. Husnain, M.; Qureshi, I.; Fatima, T.; Akhtar, W. The impact of electronic word-of-mouth on online impulse buying behavior: The moderating role of Big 5 personality traits. J. Acc. Mark. 2016, 5, 1-10. [CrossRef]

41. Smith, K.T. Digital marketing strategies that Millennials find appealing, motivating, or just annoying. J. Strateg. Mark. 2011, 19, 489-499. [CrossRef]

42. Harrigan, P.; Evers, U.; Miles, M.; Daly, T. Customer engagement with tourism social media brands. Tour. Manag. 2017, 59, 597-609. [CrossRef]

43. Popp, B.; Woratschek, H. Introducing branded communities in sport for building strong brand relations in social media. Sport Manag. Rev. 2016, 19, 183-197. [CrossRef]

44. Alalwan, A.A.; Rana, N.P.; Algharabat, R.; Tarhini, A. A systematic review of extant literature in social media in the marketing perspective. In Proceedings of Conference on e-Business, e-Services and e-Society; Springer: Cham, Switzerland, 2016; pp. 79-89.

45. Khan, F.; Siddiqui, K. The importance of digital marketing. An exploratory study to find the perception and effectiveness of digital marketing amongst the marketing professionals in Pakistan. J. Inf. Syst. Oper. Manag. 2013, 7, 12-19.

46. Abrar, M.; Bashir, M.; Safeer, A.A.; Shabbir, R.; Baig, S.A. Pakistani Ready-made Garments Industry Export Competitiveness: Evaluation in The Context of Porter's Diamond Theory. Rev. Publicando 2019, 5, 228-246.

47. Nasir, S.; Vel, P.; Mateen, H. Social media and buying behaviour of women in Pakistan towards the purchase of textile garments. Bus. Manag. Dyn. 2012, 2, 61-69.

48. Duffett, R.G. Facebook advertising's influence on intention-to-purchase and purchase amongst Millennials. Internet Res. 2015, 25, 498-526. [CrossRef]

49. Smith, B.G.; Gallicano, T.D. Terms of engagement: Analyzing public engagement with organizations through social media. Comput. Hum. Behav. 2015, 53, 82-90. [CrossRef]

50. Rutter, R.; Roper, S.; Lettice, F. Social media interaction, the university brand and recruitment performance. J. Bus. Res. 2016, 69, 3096-3104. [CrossRef]

51. Kaplan, A.M.; Haenlein, M. Users of the world, unite! The challenges and opportunities of Social Media. Bus. Horiz. 2010, 53, 59-68. [CrossRef] 
52. Muntinga, D.G.; Moorman, M.; Smit, E.G. Introducing COBRAs: Exploring motivations for brand-related social media use. Int. J. Advert. 2011, 30, 13-46. [CrossRef]

53. Naaman, M.; Becker, H.; Gravano, L. Hip and trendy: Characterizing emerging trends on Twitter. J. Am. Soc. Inf. Sci. Technol. 2011, 62, 902-918. [CrossRef]

54. Sano, K. Do social media marketing activities enhance customer satisfaction, promote positive WOM and affect behavior intention. Doshisha Commer. J. 2014, 4, 45-69.

55. Keller, K.L. Conceptualizing, measuring, and managing customer-based brand equity. J. Mark. 1993, 57, 1-22. [CrossRef]

56. Molinillo, S.; Ekinci, Y.; Japutra, A. A consumer-based brand performance model for assessing brand success. Int. J. Mark. Res. 2018, 61, 93-110. [CrossRef]

57. Netemeyer, R.G.; Krishnan, B.; Pullig, C.; Wang, G.; Yagci, M.; Dean, D.; Ricks, J.; Wirth, F. Developing and validating measures of facets of customer-based brand equity. J. Bus. Res. 2004, 57, 209-224. [CrossRef]

58. Leung, X.Y.; Bai, B.; Stahura, K.A. The marketing effectiveness of social media in the hotel industry: A comparison of Facebook and Twitter. J. Hosp. Tour. Res. 2015, 39, 147-169. [CrossRef]

59. Gamboa, A.M.; Gonçalves, H.M. Customer loyalty through social networks: Lessons from Zara on Facebook. Bus. Horiz. 2014, 57, 709-717. [CrossRef]

60. Christou, E. Branding social media in the travel industry. Procedia-Soc. Behav. Sci. 2015, 175, 607-614. [CrossRef]

61. Charo, N.; Sharma, P.; Shaikh, S.; Haseeb, A.; Sufya, M. Determining the impact of eWOM on brand image and purchase intention through adoption of online opinions. Int. J. Humanit. Manag. Sci. (IJHMS) 2015, 3, $41-46$.

62. Crofton, S.; Parker, R. Economic impacts of introducing social media as marketing tools in Atlantic Canadian tourism websites. In Proceedings of the Economic Business and Historical Society Annual Conference, Canberra, Australia, 16-18 February 2012; pp. 210-231.

63. Jiang, W.-H.; Li, Y.-Q.; Liu, C.-H.; Chang, Y.-P. Validating a multidimensional perspective of brand equity on motivation, expectation, and behavioural intention: A practical examination of culinary tourism. Asia Pac. J. Tour. Res. 2017, 22, 524-539. [CrossRef]

64. Lasorsa, D.L.; Lewis, S.C.; Holton, A.E. Normalizing Twitter: Journalism practice in an emerging communication space. J. Stud. 2012, 13, 19-36. [CrossRef]

65. Onyancha, O.B. Social media and research: an assessment of the coverage of South African universities in ResearchGate, Web of Science and the Webometrics Ranking of World Universities. S. Afr. J. Libr. Inf. Sci. 2015, 81, 8-20. [CrossRef]

66. Chen, L.; Li, Y.-Q.; Liu, C.-H. How airline service quality determines the quantity of repurchase intention-Mediate and moderate effects of brand quality and perceived value. J. Air Transp. Manag. 2019, 75, 185-197. [CrossRef]

67. Kim, S.; Park, H. Effects of various characteristics of social commerce (s-commerce) on consumers' trust and trust performance. Int. J. Inf. Manag. 2013, 33, 318-332. [CrossRef]

68. Ertürk, A.; Vurgun, L. Retention of IT professionals: Examining the influence of empowerment, social exchange, and trust. J. Bus. Res. 2015, 68, 34-46. [CrossRef]

69. Palmer, A.; Koenig-Lewis, N.; Asaad, Y. Brand identification in higher education: A conditional process analysis. J. Bus. Res. 2016, 69, 3033-3040. [CrossRef]

70. Chau, P.Y. Reexamining a model for evaluating information center success using a structural equation modeling approach. Decis. Sci. 1997, 28, 309-334. [CrossRef]

71. Shafi, M.; Yang, Y.; Khan, Z.; Yu, A. Vertical Co-operation in Creative Micro-Enterprises: A Case Study of Textile Crafts of Matiari District, Pakistan. Sustainability 2019, 11, 920. [CrossRef]

72. Fornell, C.; Larcker, D.F. Evaluating structural equation models with unobservable variables and measurement error. J. Mark. Res. 1981, 18, 39-50. [CrossRef]

73. Ngo, L.V.; O'Cass, A. In search of innovation and customer-related performance superiority: The role of market orientation, marketing capability, and innovation capability interactions. J. Prod. Innov. Manag. 2012, 29, 861-877. [CrossRef]

74. Preacher, K.J.; Hayes, A.F. Asymptotic and resampling strategies for assessing and comparing indirect effects in multiple mediator models. Behav. Res. Methods 2008, 40, 879-891. [CrossRef] [PubMed] 
75. Holsing, C.; Schultz, C.D. Empirical insights on the effect of user-generated website features on micro-conversions. Int. J. E-Bus. Res. (IJEBR) 2013, 9, 33-46. [CrossRef]

76. Kim, N.; Kim, W. Do your social media lead you to make social deal purchases? Consumer-generated social referrals for sales via social commerce. Int. J. Inf. Manag. 2018, 39, 38-48. [CrossRef]

(C) 2019 by the authors. Licensee MDPI, Basel, Switzerland. This article is an open access article distributed under the terms and conditions of the Creative Commons Attribution (CC BY) license (http://creativecommons.org/licenses/by/4.0/). 